\title{
Benthic grazers and suspension feeders: which one assumes the energetic dominance in Königshafen?
}

\author{
H. Asmus \\ Biologische Anstalt Helgoland, Wattenmeerstation Sylt; D-25992 List, \\ Federal Republic of Germany
}

\begin{abstract}
Size-frequency histograms of biomass, secondary production, respiration and energy flow of 4 dominant macrobenthic communities of the intertidal bay of Königshafen were analysed and compared. In the shallow sandy flats (Nereis-Corophium-belt [N.C.-belt], seagrass-bed and Arenicola-flat) a bimodal size-frequency histogram of biomass, secondary production, respiration and energy flow was found with a first peak formed by individuals within a size range of 0.10 to $0.32 \mathrm{mg}$ ash free dry weight (AFDW). In this size range, the small prosobranch Hydrobia ulvae was the dominant species, showing maximal biomass as well as secondary production, respiration and energy flow in the seagrass-bed. The second peak of the size-frequency histogram was formed by the polychaete Nereis diversicolor with individual weights of 10 to $18 \mathrm{mg}$ AFDW in the N.C.-belt, and by Arenicola marina with individual weights of 100 to $562 \mathrm{mg}$ AFDW in both of the other sand flats. Biomass, productivity, respiration and energy flow of these polychaetes increased from the Nereis-Corophium-belt, to the seagrass-bed, and to the Arenicola-flat. Mussel beds surpassed all other communities in biomass and the functional parameters mentioned above. Size-frequency histograms of these parameters were distinctly unimodal with a maximum at an individual size of 562 to $1000 \mathrm{mg}$ AFDW. This size group was dominated by adult specimens of Mytilus edulis. Averaged over the total area, the size-frequency histogram of energy flow of all intertidal flats of Königshafen showed one peak built by Hydrobia ulvae and a second one, mainly formed by $M$. edulis. Assuming that up to $10 \%$ of the intertidal area is covered by mussel beds, the maximum of the size-specific energy flow will be formed by Mytilus. When only $1 \%$ is covered by mussel beds, then the energy flow is dominated by $H$. ulvae. Both animals represent different trophic types and their dominance in energy flow has consequences for the food web and the carbon flow of the total area. If the energy flow of the macrozoobenthos of Königshafen is dominated by $M$. edulis, then the primary energy has to be gained from the pelagic primary production and the total ecosystem will be dependent on energy input from the North Sea and deeper parts of the adjacent Wadden Sea. In the case of a dominance of $H$. ulvae, the energy flow of Königshafen is mainly based on autochthonous primary production.
\end{abstract}

\section{INTRODUCTION}

Many parameters structuring faunal assemblages show a distinct size distribution. The relation between abundance and body size has been modelled as a power function. From terrestrial populations, some authors have reported negative exponents (Brown \& Maurer, 1986; Damuth, 1987; 1991), while others show exponents not significantly different from zero (Morse et al., 1988). The former implies that in these populations, specimens use equivalent amounts of energy regardless of their body size, while the latter implies an energetic dominance by larger individuals (Griffiths, 1992). The slope of 
abundance-size relations may be a test of the hypothesis that energy availability limits the abundance of differently sized organisms. In natural assemblages, this is only true for dominant species (Blackburn et al., 1993). Since the energy supply is also size-dependent, the size distribution has a major impact on respiration (Gerlach et al., 1985), growth processes (Schwinghamer et al., 1986; Edgar, 1990 a, Barry \& Tegner, 1990) and, as a result, on the biomass of an animal assemblage (Heip et al., 1984; Boudreaux \& Dickie, 1992). Showing the size-dependence of these parameters, it will be possible to obtain information on the effects of animal size within the food web. As a paradigm, predation is strongly related to prey size and, if so, the energy flow from one trophic level to the next will be size-controlled (Cohen et al., 1993).

Structuring the metabolic and growth parameters of an animal assemblage in relation to body size may lead to a way to predict the dynamic role of animal assemblages on the ecosystem level. The importance of body size for productivity of marine fauna is recognized by many authors (Banse \& Mosher, 1980; Schwinghamer et al., 1986), mainly from a theoretical point of view. Recent investigations show the practical applicability of making use of the size structure for measurements of secondary production (Edgar, 1990a).

In the tidal flats of Königshafen, macrofauna shows a wide range of sizes from small oligochaetes to large adult mussels and polychaetes. The question arises, whether dominant macrofaunal assemblages show different size-frequency histograms of metabolic and growth characteristics and what the reasons and consequences are for the entire ecosystem.

\section{MATERIAL AND METHODS}

\section{Study site}

Königshafen is a small intertidal bay $\left(4 \mathrm{~km}^{2}\right)$, situated at the northern tip of the island of Sylt in the North Sea. Sand dunes form a small sandbar which protects the bay in the north and the west from the open North Sea. To the east, the bay is open to the Wadden Sea. The tidal flats are drained by a central channel. The average tidal range is about $1.8 \mathrm{~m}$, with only minor deviations due to neap and spring tides or strong winds. The sediments are mainly sandy with a distinct share of windborne sand from adjacent dunes. Muddy sediments are only found in a sheltered basin in the west. For this investigation, 4 sites were selected which are assumed to be representative of the dominant macrofaunal assemblages. The Nereis-Corophium-belt ( $N$.-C.-belt) borders the mean high tide line and is 20 to $100 \mathrm{~m}$ wide. It is inundated for nearly $2 \mathrm{~h}$ during a tidal cycle. The upper part of the sand flat is covered by seagrass-beds which are inundated $4-5 \mathrm{~h}$ during a tidal cycle. On sandy sites, the small seagrass Zostera noltii is dominant, whereas on mud Zostera marina is more abundant. On bare sandflats from the upper shore down to the low-water line, the lugworm Arenicola marina shapes the character of the sediment. Because of the wide distribution of this assemblage over a wide range of tidal levels, a study site at mean-tide level (inundation of $6 \mathrm{~h}$ per tidal cycle) was selected. This Arenicola-flat has the greatest share in the total area of Königshafen. Near the low-tide line, mussels form dense beds. The areal coverage of mussel beds varied in the past particularly due to ice scour during severe winters and dredging by an expanding mussel fishery. The areal extension of the macrofaunal assemblages is shown in Table 1. 
Table 1. Areal extension of macrofaunal assemblages of Königshafen in $10^{6} \mathrm{~m}^{2}$, considering different situations of areal coverage by mussel beds. Mud flats $\left(0.3\right.$ to $\left.0.4 \times 10^{6} \mathrm{~m}^{2}\right)$ are not considered

\begin{tabular}{|lll|}
\hline Community & $1 \%$ & $10 \%$ \\
\hline Nereis-Corophium-belt & 0.34 & 0.34 \\
Seagrass-bed & 0.31 & 0.46 \\
Arenicola-flat & 3.03 & 2.45 \\
Mussel bed & 0.05 & 0.48 \\
\hline
\end{tabular}

\section{Sampling procedure}

Biomass data from macrofauna of the three sand flat communities were obtained during an investigation of productivity and community metabolism in 1980 . Two cores (area: $600-700 \mathrm{~cm}^{2}$ ) were examined every month in each of these assemblages in order to measure biomass and secondary production. A subsample of $10 \times 10 \mathrm{~cm}$ surface area was taken from these cores and sieved through a 500- $\mu$ m mesh sieve. This subsample was used to analyse biomass and abundance of the smaller macrofauna, such as Hydrobia ulvae, Pygospio elegans, juvenile polychaetes and oligochaetes. The rest of the sediment was sieved through a 1000- $\mu \mathrm{m}$ sieve, to retain the larger macrofauna. Due to the greater variability in the structure of habitat, 6 core samples (surface $10 \times 10 \mathrm{~cm}$ ) were taken at 6 sites of the mussel bed every month during the whole of 1984 . The samples were sieved through $500-\mu \mathrm{m}$ mesh. From these samples, the total macrofauna was counted at the species level. When animals occurred over a larger size range, different size classes were counted separately.

\section{Determination of biomass and secondary production}

The macrofaunal material was separated into species and size groups. These samples were dried at $75^{\circ} \mathrm{C}$ for about 3 days. After cooling in a desiccator, the samples were weighed. To determine ash free dry weight (AFDW), all samples were burnt in a furnace at $550{ }^{\circ} \mathrm{C}$. These data were used to estimate the individual weight as well as the biomass per square metre of species and size groups.

Secondary production was estimated for each species and size group from changes in individual weight and from the mean abundance between two subsequent sampling dates (Crisp, 1984; Asmus, 1987; Brey, 1990). These monthly estimates were extrapolated to one square metre, and added up for a one-year period for species and size classes separately. Summing up yearly production values of all species of a common size group gave the secondary production of this size group. In order to compare biomass and production values with carbon flow, $1 \mathrm{~g}$ AFDW was assumed to correspond to $0.58 \mathrm{~g} \mathrm{C}$ (derived from Jannsson \& Wulff, 1977; Remmert, 1980).

\section{Respiration measurements}

For the dominant macrofauna species, respiration measurements were carried out in closed chambers in the laboratory under in situ temperatures. From these measurements 
an allometric regression was calculated between respiration and individual weight for each of the dominant species (Asmus, 1984). Respiration rates of rare species were estimated from the individual sizes, using the allometric regression of the dominant species most similar in taxonomic order and size. Respiration from these experiments was assumed to reflect a mean routine metabolism of the species investigated. Hourly respiration was converted to daily respiration considering the mean inundation time of the community. Respiration during low tide was assumed to be negligible. Most of the investigated species are inactive during low tide, and meet their metabolic requirements by anaerobiosis. This induces an oxygen debt which will be compensated at the beginning of the next inundation. To consider this special activity mode in the respiration measurements, the animals were kept at low-tide conditions before the experiment started. Respiration measurements were carried out for the duration of the mean natural inundation period. For conversion of $1 \mathrm{ml} \mathrm{O}_{2}$ in $\mathrm{g} \mathrm{C}$ an oxicaloric equivalent of $4687 \mathrm{cal}$ per $\mathrm{ml} \mathrm{O}_{2}$ was assumed, corresponding to $0.38 \mathrm{~g} \mathrm{C}$ per $\mathrm{ml} \mathrm{O}_{2}$.

The size-specific energy flow of the entire macrofauna was estimated from the sum of both secondary production and respiration per square metre and year for every size range expressed in $\mathrm{g} \mathrm{C}$.

\section{RESULTS}

\section{Size-frequency histogram of macrofaunal biomass}

The size-frequency histogram of macrofaunal biomass showed a bimodal curve in the Nereis-Corophium-belt, the seagrass-bed and the Arenicola-flat (Fig. 1). Maximum biomass was found in a size group of individual weights of 0.18 to $0.32 \mathrm{mg}$ AFDW in the three communities. This size group consisted mainly of the small prosobranch Hydrobia ulvae. In the seagrass-bed, this maximum showed higher biomass values than in both other communities. A second biomass peak was found at individual weights of 10.00 to $17.78 \mathrm{mg}$ AFDW in the Nereis-Corophium-belt, at individual weights of 100.00 to $177.83 \mathrm{mg}$ AFDW in the seagrass-bed, and of 316.22 to $562.34 \mathrm{mg}$ AFDW in the Arenicola-flat. In the Nereis-Corophium-belt, this second peak originated from the polychaete Nereis diversicolor. In both other sand bottom communities, Arenicola marina contributed most of the biomass within this size peak, showing a shift to a higher individual weight due to the longer inundation of the Arenicola-flat. In the mussel bed, the size histogram of biomass was unimodal, showing a maximum at a size group of an individual weight of $0.562-1.0 \mathrm{~g}$ AFDW. This maximum was due to adult mussels Mytilus edulis. The biomass-size histograms reveal a change in dominance from small sized macrofauna in shallow, shortly inundated parts of the tidal flat to the dominance of larger macrofauna near the low tide level.

\section{Size-frequency histograms of secondary production}

Size-frequency histograms of the secondary production show a bimodal pattern in the three sand bottom communities (Fig. 2) similar to the biomass-size spectra. In the Arenicola-flat an additional peak is found in the size class of 1.78-3.16 mg AFDW, which was formed by juveniles of the bivalve Macoma balthica. The highest production was found at the same individual size as the maximum biomass in the Nereis-Corophium-belt 


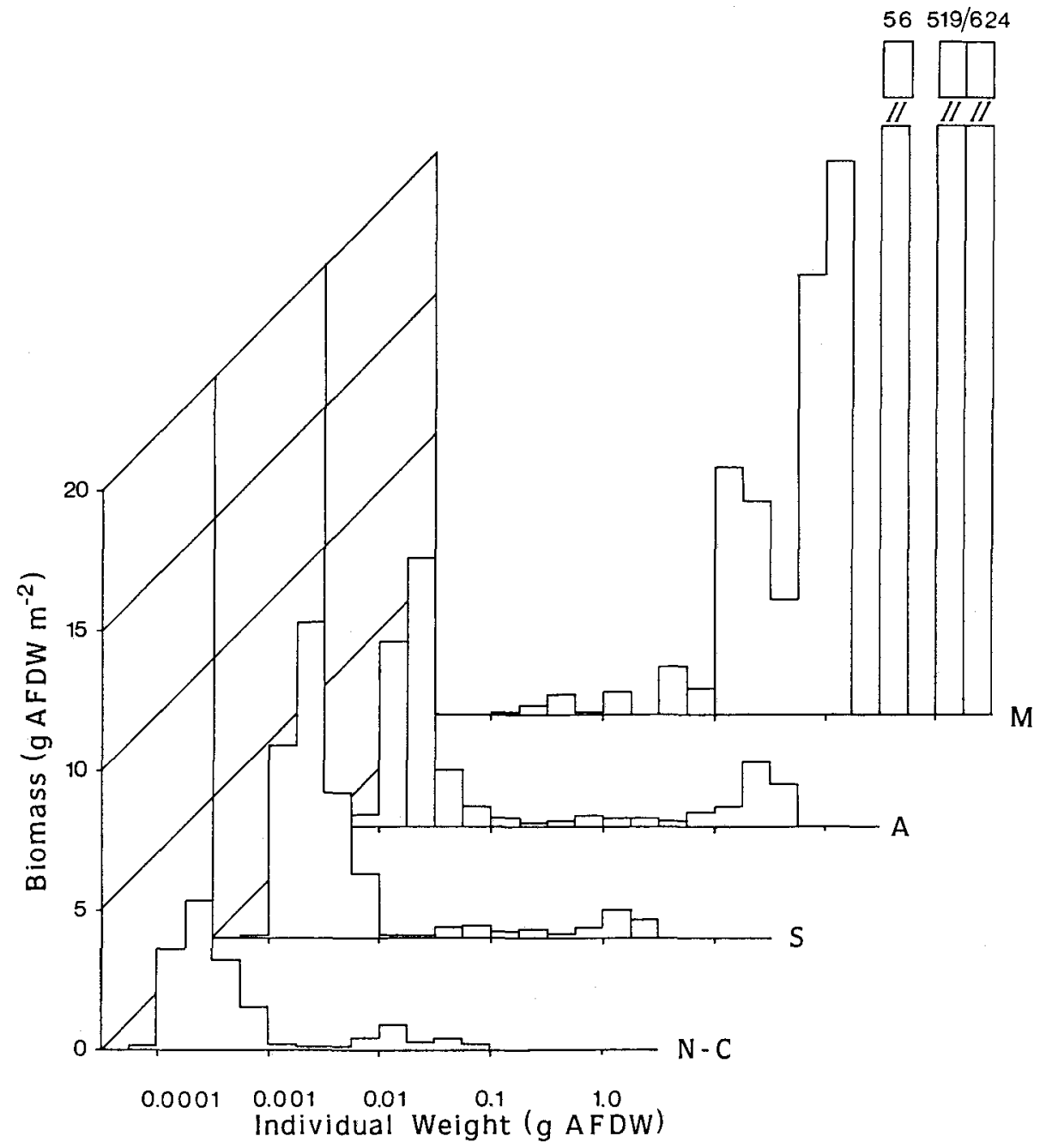

Fig. 1. Size-spectra of macrozoobenthic biomass $\left(\mathrm{g} \mathrm{AFDW} \mathrm{m}^{-2}\right.$ ) and individual weight ( $\mathrm{g}$ AFDW) of 4 intertidal macrofaunal assemblages of Königshafen. Biomass is indicated as the sum of total biomass of macrofaunal species, averaged over one year, estimated for each size-class. N-C: NereisCorophium-belt; S: seagrass-bed; A: Arenicola-flat; M: mussel bed.

and the seagrass-bed, whereas in the Arenicola-flat this was found in a lower size range $(0.10$ to $0.18 \mathrm{mg}$ AFDW) than that of maximum biomass. This may be due to the greater abundance of juvenile Hydrobia ulvae, which tend to grow faster and thus will have a greater production to biomass ratio than older and larger specimens. Maximum production contributed to 51,61 and $19 \%$ to the total production of the N.C.-belt, the seagrassbed and the Arenicola-flat, respectively. As demonstrated for biomass, the production of this dominant size class was highest in the seagrass-bed. The second peak of the production-size curve was found at an individual weight of 31.62 to $56.24 \mathrm{mg}$ (N.C.-belt), 


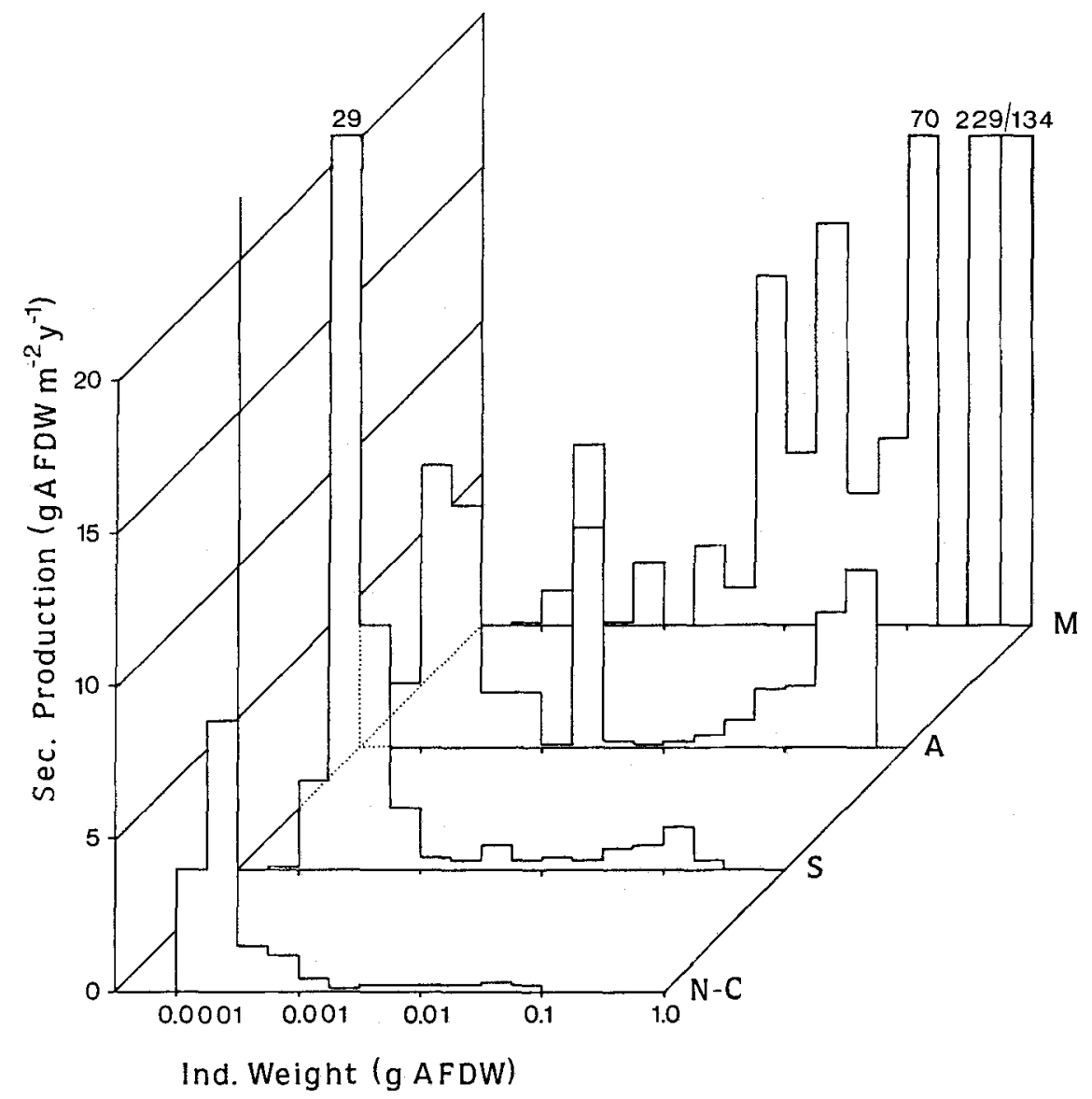

Fig. 2. Size-spectra of macrozoobenthic secondary production $\left(\mathrm{g} A F D W \mathrm{~m}^{-2} \mathrm{y}^{-1}\right.$ ) and individual weight (g AFDW) of 4 intertidal macrofaunal assemblages of Königshafen. Indicated values repre* sent the sum of annual secondary production of each species estimated for each size-class. N-C:

Nereis-Corophium-belt, S: seagrass-bed; A: Arenicola-flat; M: mussel bed.

100.00 to $177.83 \mathrm{mg}$ (seagrass-bed) and 316.23 to $562.34 \mathrm{mg}$ AFDW (Arenicola-flat). The longer the inundation time of the community, the higher the individual weight of animals forming this peak. Additionally, the height of production within this peak increases in the same order. In the mussel bed, $47 \%$ of the secondary production is formed by the size group of an individual weight of 562.34 to $1000.00 \mathrm{mg}$ AFDW. This size group consisted mainly of adult Mytilus edulis, but these mussels have a lower individual weight than those contributing to maximum biomass. Nevertheless, maximum production is found in the upper range of the whole size spectrum, revealing a unimodal production-sizehistogram.

\section{Macrofaunal respiration}

The size histogram of macrofaunal respiration reflects similar patterns to those observed in biomass and secondary production. The highest respiration was found at the 


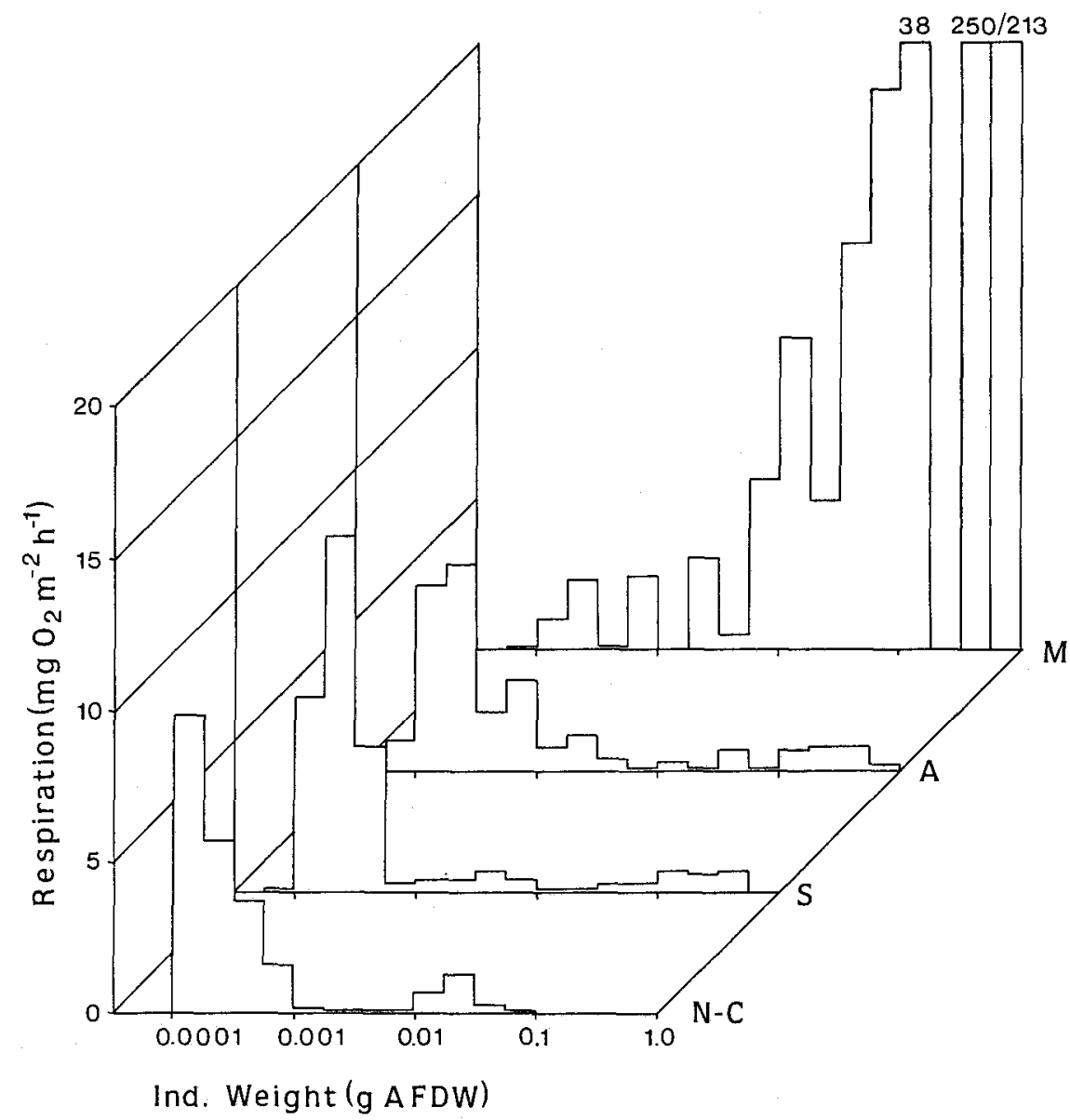

Fig. 3. Size-spectra of macrozoobenthic respiration $\left(\mathrm{mg} \mathrm{O}_{2} \mathrm{~m}^{-2} \mathrm{~h}^{-1}\right)$ and individual weight (g AFDW) of 4 intertidal macrofaunal assemblages of Königshafen. The respiration values indicate the sum of the average respiration rate per hour of each species estimated for each size-class. N-C: NereisCorophium-belt; S: seagrass-bed; A: Arenicola-flat; M: mussel bed.

lower size ranges in the three sand bottom communities (Fig. 3). Forty-two \% of the total macrofaunal respiration were used by Hydrobia ulvae of the size class of 0.10 to $0.18 \mathrm{mg}$ AFDW in the N.C.-belt. In the seagrass-bed and the Arenicola-flat, the maximum of respiration ( $43 \%$ and $27 \%$, respectively) originated from $H$. ulvae with a size of 0.18 to $0.32 \mathrm{mg}$ AFDW. Nereis diversicolor (size range: 17.78 to $31.62 \mathrm{mg}$ AFDW) caused a second respiration peak in the N.C.-belt, and Arenicola marina $(100.00$ to $316.22 \mathrm{mg}$ AFDW) in the seagrass-bed ( $2.5 \%$ ) and in the Arenicola-flat ( $3.2 \%)$. Between maximum respiration at the lower size ranges and the second respiration peak, there was an area of minimum values responding to individual sizes of 1.78 to $10.00 \mathrm{mg}$ AFDW. Maximum respiration ( $44 \%$ of the total respiration) in the mussel bed was found in the upper size range of adult $M$. edulis. The shape of the size-specific respiration curve was equivalent to that of secondary production. Minimum respiration was found at sizes of less than 
$0.32 \mathrm{mg}$ AFDW. Total respiration was highest in the mussel bed (1748 $\left.\mathrm{g} \mathrm{C} \mathrm{m}^{-2} \mathrm{y}^{-1}\right)$ followed by the seagrass-bed ( $56 \mathrm{~g} \mathrm{C} \mathrm{m}^{-2} \mathrm{y}^{-1)}$, the Arenicola-flat $\left(39 \mathrm{~g} \mathrm{C} \mathrm{m}^{-2} \mathrm{y}^{-1}\right)$ and the Nereis-Corophium-belt $\left(24 \mathrm{~g} \mathrm{C} \mathrm{m}^{-2} \mathrm{y}^{-1}\right)$.

\section{Size-specific energy flow}

Total net energy flow of the communities decreased from the low-tide line to the upper shore. Highest values were estimated for the mussel bed $\left(2023 \mathrm{~g} \mathrm{C} \mathrm{m}^{-2} \mathrm{y}^{-1}\right)$ and the seagrass-bed $\left(85 \mathrm{~g} \mathrm{C} \mathrm{m}^{-2} \mathrm{y}^{-1}\right)$. In the Arenicola-flat $\left(69 \mathrm{~g} \mathrm{C} \mathrm{m}^{-2} \mathrm{y}^{-1}\right)$ and in the N.C.belt $\left(35 \mathrm{~g} \mathrm{C} \mathrm{m}^{-2} \mathrm{y}^{-1}\right.$ ) energy flow was lower. Size-specific energy flow had a similar bimodal shape as the spectra of biomass, secondary production and respiration for the three sand bottom communities. Energy flow of these communities can be related to two macrofaunal size groups. The first group consisted of small specimens, mainly Hydrobia ulvae, with a size range from $<0.10$ to $1.78 \mathrm{mg}$ AFDW. Within this group, the energy flow was normally distributed over the entire size ranges. In the N.C-belt, the seagrass-beds and the Arenicola-flat, respectively $93 \%, 95 \%$ and $78 \%$ of the energy flowing through the macrofauna was concentrated in this group. The share in energy flow of the second group, with a size range larger than $1.78 \mathrm{mg}$ AFDW, was comparably low. The energy flow in this group increased from the N.C.-belt to the Arenicola-flat, showing the increasing importance of larger animals with longer inundation times.

Mussel beds showed the maximum of energy flow in the upper range of size frequency. Mussel beds may control the energy flow of the total area, because their energy flow per square metre surpassed the other communities by an order of magnitude. This became obvious by a comparison of the total energy flow of the different communities, taking into account their areal extension.

The total energy flow reflected the spatial extension (Table 1). Averaged over the total area of Königshafen, the size-specific energy flow through the macrofauna was dependent on the extension of area covered by mussel beds. Because the area of mussel beds fluctuates from year to year, a comparison of the total energy flow is made between a situation of $1 \%$ (Reise et al., 1994) of the area of Königshafen covered by mussel beds and $10 \%$ coverage by mussel beds (Asmus \& Asmus, 1990) (Fig. 4). Both cases showed a bimodal-shaped curve. When $1 \%$ of the area is covered by mussels, the maximum of energy flow is formed by the small macrofauna, the dominant species being Hydrobia ulvae. When $10 \%$ of the tidal flats are covered by mussels, the maximum of energy flows through the larger macrofauna, the dominant species being Mytilus edulis.

\section{DISCUSSION}

\section{Unimodal and bimodal size distribution - What are the ecological effects?}

The bimodal pattern of size histograms in the three sand bottom communities was caused by two characteristic, clearly separated species groups. The smaller size group in the range of 0.10 to $1.78 \mathrm{mg}$ was dominated by Hydrobia ulvae, representing the trophic type of browsers. Hydrobia ulvae mainly grazes on diatoms and other microphytobenthos (Fenchel \& Kofoed, 1976; Jensen \& Siegismund, 1980), which are produced in the same habitat. The importance of a grazing food chain based on this browsing species for this 


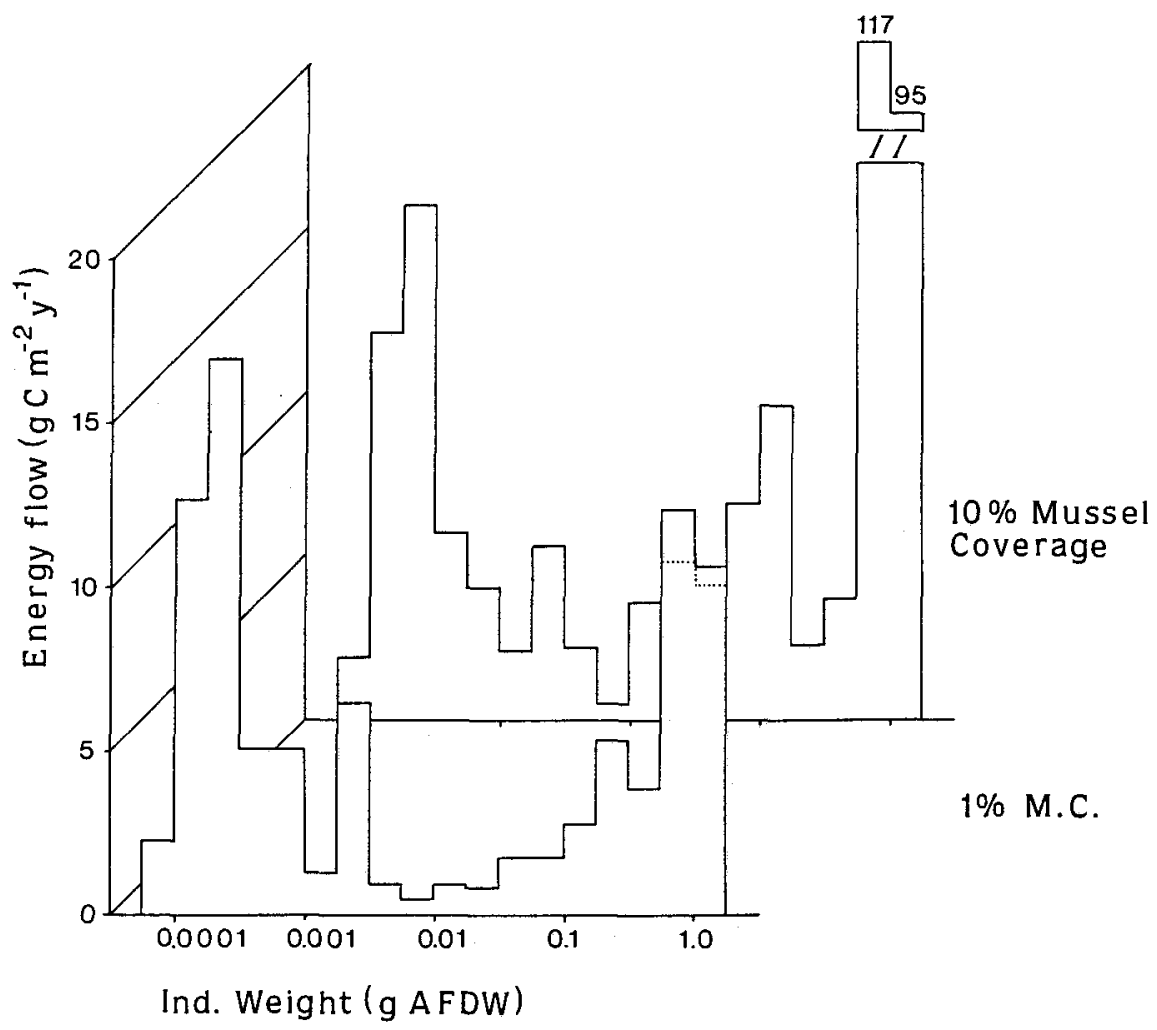

Fig. 4. Total size-specific energy flow of the intertidal macrofauna of Königshafen in relation to the different percentages of areal coverage by mussel beds. The energy flow is estimated from the sum of annual secondary production and annual respiration for each size group and represents the amount of energy assimilated from the macrofauna. For the total energy flow, the per-unit-area values of each assemblages were multiplied by the total areal coverage of the assemblage.

type of sandy intertidal flat was emphasized earlier (Asmus \& Asmus, 1985). Extrapolating this to the total tidal flat; Königshafen becomes an ecosystem with a more or less autochthonous energy flow. The energy accumulated in this part of the faunal assemblage is used only by a few epibenthic invertebrate predator species like shrimps (Crangon crangon). Many authors describe shrimps feeding on small macrofauna (Plagmann, 1939; Pihl \& Rosenberg, 1984; Pihl, 1985; Reise, 1985; Beukema, 1992). Other possible predators are juvenile shore crabs (Carcinus maenas) (Reise, 1978; Beukema, 1991) and, to a lesser extent, predatory gastropods (Retusa obtusa), nemertines and predatory polychaetes (Reise, 1981).

It is unknown whether small fish like the sand gobies feed on Hydrobia, but fish are linked to this small macrofauna group, by feeding on associated small polychaetes (Pygospio elegans) and oligochaetes (Tubificoides benedenii, Tubifex spec.) (Reise, 1978; Wolff \& Zijlstra, 1981; Raffaelli \& Milne, 1987) and by feeding on its predators, the prawns and amphipods (Raffaelli \& Milne, 1987).

Animals in this size range may be too small for an effective predation by most of the 
birds visiting the tidal flats. Shelducks (Tadorna tadorna) (Goethe,1980) and avocets (Recurvirostra avosetta) are known to feed on Hydrobia ulvae, but these birds are rare in Königshafen. Zwarts \& Blomert (1992) showed that an effective predation by knots (Calidris canutus) starts at sizes in the upper range of the size classes regarded here as the food web based on small macrofauna. Only a few species like the dunlin (Calidris alpina) may use the total size spectrum of Hydrobia (Ehlert, 1964 ${ }_{i}$ Höfmann \& Hoerschelmann, 1969; Glutz von Blotzheim et al., 1975; Mouritsen \& Jensen, 1992). The quantitative assessment of how much energy is transferred within this food web to higher trophic levels is still unknown, but the number of species which are able to profit from this group of small-sized macrofauna seems to be limited. From the present results, it is possible to estimate the amount of energy and material available from this group of macrofauna to the upper trophic levels. Lauckner (1986) reported that Hydrobia ulvae is in some places of Königshafen highly infected by parasites, but a quantification of this probably important branch of energy flow on the ecosystem level was not done.

The second distinctly separated macrofaunal group of the bimodal size histogram of the animal assemblage was dominated by different species depending on habitat. In the Nereis-Corophium-belt, this size group was formed by the polychaete Nereis diversicolor. This species has a wide range of feeding types, being omnivorous, detritivorous and predatory (Hartmann-Schröder, 1981). Because of its ability to form mucus nets as particle traps, which are fed by the worm when it is filled, Nereis has the potential to use the water column as feeding habitat (Riisgard et al., 1992). In both other sand bottom assemblages, the seagrass-bed and the Arenicola-flat, Arenicola marina dominates this second peak in the size spectrum of the assemblage. Arenicola mainly feeds on the upper sediment layer (Fauchald \& Jumars, 1979) but is also able to pump water through its burrow (Krüger, 1964; Jacobsen, 1967). The volume of water pumped in this way is small compared to the filtration capacity of a suspension feeder (Baumfalk, 1979), but nevertheless the polychaete may exploit the water column for feeding.

The second peak in the macrofauna size spectrum is dominated by species belonging to another trophic type than those dominating the food web based on small macrofauna. These species are important prey organisms, especially for a large number of wading birds like bar-tailed godwits (Limosa lapponica) (Smith \& Evans, 1973; Piersma et al., 1980), curlews (Numenius arquata) (Boere \& Smit, 1980), dunlins (Calidris alpina), redshanks (Tringa totanus), and oyster catchers (Haematopus phaeopus), that visit the tidal flats of Königshafen frequently. Predation by fish is probably less important for the "large food web", because most of the species are endobenthic, but predation on syphon tips, tail ends and other regenerable parts of the body contribute to a considerable amount to the diet of some predators (de Vlas, 1979). The amount of energy or material available from this part of the faunal assemblages increases with increasing inundation time. Whether this is a consequence of decreasing bird predation, or increasing food supply due to increasing inundation time, is not clear. Considering the trophic role of the Wadden Sea, the larger benthic species are generally regarded as the base of the food web of the ecosystem (Beukema, 1981). However, in the sand bottom habitats of Königshafen, this part of the benthic community contributes only 10 to $30 \%$ to the total energy flow.

Unimodal size-frequency histograms of biomass, secondary production and respiration were found at all sites of mussel beds in Königshafen. The maximum of the size 
spectrum was formed by the large Mytilus edulis in the size range of 0.56 to $1.00 \mathrm{~g}$. Size spectra of biomass and secondary production are discussed in Asmus (1987). Main predators on mussels in this size-range are oystercatchers (Haematopus ostralegus) and Eiderducks (Somateria mollissima). Because of the dominance of the blue mussel in this assemblage, suspension feeding is the main mode of energy acquisition for the macrofaunal assemblage. More than the other assemblages, the mussel beds depend on pelagic primary production and pelagic particle import (Asmus \& Asmus, 1990). The biomass maximum, as well as the maxima for secondary production and respiration, surpass the biomass peak at a similar size-class of the sand bottom assemblages.

Barry \& Tegner (1990) discuss the possible demographic background leading to bimodal or unimodal size-frequency distribution within a population. In a model, they showed that the pattern of a size-frequency histogram is mainly influenced by the mortality rate and the growth rate. Under the assumption that these parameters, as well as the recruitment, are constant, no bimodal or unimodal shapes of the size-distributions are possible. Shifts in the ratio of mortality to growth with age from a growth-dominated to a mortality-dominated population result in a strongly unimodal size-frequency distribution. Stable bimodal distributions require shifts from mortality-dominated to growthdominated conditions via age-related changes in mortality or growth, or both. Nonequilibrium conditions or events such as pulses in recruitment or mortality can also modify size-frequency distributions, but these effects are usually transient. In contrast to populations, size-specific growth and mortality in assemblages are additionally variable due to different rates of species and ages. These results indicate that inferences concerning the demographic dynamics are more difficult to derive from observing the shape of size-distribution on the assemblage level compared to the population level.

This study demonstrates that on the sandy tidal flats of Königshafen, the macrofaunal assemblage is formed by two separate size-groups with different ecological effects on the total ecosystem, because both groups use different energy sources and direct the energy into different pathways. The habitat of a mussel bed is dominated by suspension feeders occupying the total size-range of the assemblage.

\section{Size-distribution and tidal level: a key to energy use of a community?}

The size-distribution of biomass and secondary production varies among the different assemblages of a tidal flat. A simple and widespread explanation is to refer increases in biomass and secondary production of populations - from the high-tide line to the lowtide line - to the increasing energy availability due to inundation. Harvey \& Vincent (1990) showed higher growth of Macoma balthica at levels with longer inundation times: additional growth differences within the size range of the population were obvious from the high- to low-tide line.

In the present study, the small macrofauna revealed a maximum energy flow in the seagrass-bed ecosystem situated at the upper part of the tidal flat, whereas near the lowtide line, biomass and secondary production of this group were less important. For the food web based on small macrofauna, the energy availability seems, therefore, to be independent of the tidal level, because this food web is based on grazing of microphytobenthos, which is higher in seagrass beds by the additional availability of epiphytes. Edgar (1990b) also found an increase in biomass and secondary production due to the 
increase of plant material in seagrass-beds, but he related the elevated biomass values to the higher availability of detritus from decaying plants. Most of the seagrass-beds in Königshafen are formed by populations of Zostera noltii, growing on sandy sediments with very low shares of plant detritus (Wille, pers. comm.). The higher biomass of smallsized macrofauna in seagrass-beds may be due to better grazing conditions in the first place and secondly to protection from predation (Reise, 1978) and turbulence. Turbulence and currents may be the reason for worse grazing conditions in the deeper tidal levels, because sediment stability is low; thus, growth conditions for microphytobenthos are not as good as in the upper tidal flat (de Jonge, 1992) despite good light conditions.

The large macrofauna shows an increase in biomass, secondary production and energy flow with increasing inundation period. When going down the shore, the dominant species, and accordingly the dominant feeding type, changes from omnivorous to suspension feeding. In mussel beds, biomass and secondary production as well as energy flow show maximum development.

Grazers or suspension feeders: which one assumes the energetic dominance at the ecosystem level?

The grazing food chain is an important energy pathway on the tidal flats of Königshafen (Asmus \& Asmus, 1985). Most of the area is dominated by grazing animals like Hydrobia ulvae. However, mussel beds surpass these areas by biomass and secondary production per unit-area (Asmus, 1987; Asmus \& Asmus, 1990). The energetic dominance of one of these groups depends on the areal extension of the assemblage. Mussel beds show large variations in areal coverage and biomass from year to year (Dankers \& Koelemaij, 1989). In Königshafen, mussel beds occupy about $1 \%$ (Reise, pers. comm.) to $10 \%$ (Asmus \& Asmus, 1990) of the total area. The net energy flow (assimilated energy) related to the total tidal flat increases with an increasing share of areal coverage by mussel beds from $94 \mathrm{~g} \mathrm{C} \mathrm{m}^{-2} \mathrm{y}^{-1}$ at $1 \%$ coverage to $296 \mathrm{~g} \mathrm{C} \mathrm{m}^{-2} \mathrm{y}^{-1}$ at a $10 \%$ cover. Additionally, a shift from a weak energetic dominance of small macrofauna to a distinct energetic dominance of large macrofauna is obvious. An increase in energy flow seems to be possible only by a support of food supply from outside Königshafen.

\section{CONCLUSIONS}

Macrofaunal assemblages of the Nereis-Corophium-belt, the seagrass-bed and the Arenicola-flat each consisted of two groups, indicated by corresponding peaks in the size spectra of biomass, secondary production, respiration and energy flow.

The first size-group was mainly made up of Hydrobia ulvae. Because of the small size, this part of the assemblage may be effectively utilized by a limited species number of small waders, whereas the main energy flow is directed via predation by shrimps (Crangon crangon) to fishes. This food web is based on autochthonous primary production.

The second size group can be directly used by a lot of wading birds as well as by oystercatchers and eiderducks. Biomass as well as secondary production, respiration and energy flow of this food web based on large macrofauna increase from the high-tide line down to the low-tide line. This food web is based on different energy sources from 
benthic and pelagic production as well as from detritus input from outside the habitat. Mussel beds are dominated by this food web, surpassing the other benthic assemblages in biomass and energy flow by an order of magnitude. The energy flow of mussel beds is based on energy sources from phytoplankton production and is thus dependent upon input from deeper waters. The amount of total energy assimilated by the intertidal macrofauna of Königshafen depends on the energetic dominance of mussel beds within the macrofaunal assemblages. A high areal coverage by mussel beds increases the energy flow through the macrofauna and induces a shift from autochthonous to allochthonous energy sources.

Acknowledgements. I am grateful for the kind help of my wife Ragnhild Asmus in all stages of this work, from measurements to the final corrections of the manuscript. This work was supported by the Deutsche Forschungsgemeinschaft (As 49/1-1) and by the Federal Ministry for Research and Technology. This is publication no. 129 of the project "Ecosystem Research Wadden Sea".

\section{LITERATURE CITED}

Asmus, H., 1984. Freilanduntersuchungen zur Sekundärproduktion und Respiration benthischer Gemeinschaften im Wattenmeer der Nordsee. - Ber. Inst. Meeresk. Kiel 122, 1-171.

Asmus, H., 1987. Secondary production of an intertidal mussel bed community related to its storage and turnover compartments. - Mar. Ecol. Prog. Ser. 39, 251-266.

Asmus, H. \& Asmus, R., 1985. The importance of grazing food chain for energy flow and production in three intertidal sand bottom communities of the northern Wadden Sea. - Helgoländer Meeresunters. 39, 273-301.

Asmus, H. \& Asmus, R. M., 1990. Trophic relationships in tidal flat areas: to what extent are tidal flats dependent on imported food? - Neth. J. Sea Res. 27, 93-99.

Banse, K. \& Mosher, S., 1980. Adult body mass and annual production/biomass relationships of field populations. - Ecol. Monogr. 50 (3), 355-379.

Barry, J. P. \& Tegner, M. J., 1990. Inferring demographic processes from size-frequency distributions: simple models indicate specific patterns of growth and mortality. - Fish. Bull. 88, 13-19.

Baumfalk, Y. A., 1979. On the pumping activity of Arenicola marina. - Neth. J. Sea Res. 13 (3/4). $422-427$.

Beukema, J. J., 1981. Quantitative data on the benthos of the Wadden Sea proper. In: Invertebrates of the Wadden Sea. Ed. by N. Dankers, H. Kühl \& W. J. Wolff. Balkema, Rotterdam, 134-142.

Beukema, J. J., 1991. The abundance of shore crabs Carcinus maenas (L.) on a tidal flat in the Wadden Sea after cold and mild winters. - J. exp. mar. Biol. Ecol. 153, 97-113.

Beukema, J. J., 1992. Dynamics of juvenile shrimp Crangon crangon in a tidal-flat nursery of the Wadden Sea after mild and cold winters. - Mar. Ecol. Prog. Ser. 83, 157-165.

Blackburn, T. M., Brown, V. K., Doube, B. M., Greenwood, J. D., Lawton, J. H. \& Stork, N. E., 1993. The relationship between abundance and body size in natural animal assemblages. - J. Anim. Ecol. 62, 519-528.

Boere, G. C. \& Smit, C. J., 1980. Curlew (Numenius arquata). In: Birds of the Wadden Sea. Ed. by C. J. Smit \& W. J. Wolff. Balkema, Rotterdam, 179-188.

Boudreaux, P. R. \& Dickie, L. M., 1992. Biomass spectra of aquatic ecosystems in relation to fisheries yield. - Can. J. Fish. aquat. Sci. 49, 1528-1538.

Brey, T., 1990. Estimating productivity of macrobenthic invertebrates from biomass and mean individual weight. - Meeresforsch. 32, 329-343.

Brown, J. H. \& Maurer, B. A., 1986. Body size, ecological dominance and Copés rule. - Nature, Lond. $324,248-250$.

Cohen, J. E., Pimm, S. L., Yodzis, P. \& Saldana, J., 1993. Body sizes of animal predators and animal prey in food webs. $-J$. Anim. Ecol. $62,67-78$.

Crisp, D. J., 1984. Energy flow measurements. In: Methods for the study of marine benthos. Ed. by N. A. Holme \& A. D Mc Intyre. Blackwell, Oxford, 284-372. 
Damuth, J. 1987. Interspecific allometry of population density in mammals and other animals: the independence of body mass and population energy use. - Biol. J. Linn. Soc. 31, 193-246.

Damuth, J., 1991. Of size and abundance. - Nature, Lond. 351, 268-269.

Dankers, N. \& Koelemaij, K., 1989. Variations in the mussel population of the Dutch Wadden Sea in relation to monitoring of other ecological parameters. - Helgoländer Meeresunters. 43, 529-535.

Edgar, G. J., 1990a. The use of the size structure of benthic macrofaunal communities to estimate faunal biomass and secondary production. - J. exp. mar. Biol. Ecol. 137, 195-214.

Edgar, G. J., 1990b. The influence of plant structure on the species richness, biomass and secondary production of macrofaunal assemblages in Western Australian seagrass beds. - J. exp. mar. Biol. Ecol. 137, 215-240.

Ehlert, W., 1964. Zur Ökologie und Biologie der Ernährung einiger Limikolenarten. - J. Orn. 105, $1-53$.

Fauchald, K. \& Jumars, P. A., 1979. The diet of worms: a study of polychaete feeding guilds. Oceanogr. mar. Biol. a. Rev. 17, 193-284.

Fenchel, T. \& Kofoed, L. H., 1976. Evidence for exploitative interspecific competition in mud snails (Hydrobiidae). - Oikos 27, 367-376.

Gerlach, S. A., Hahn, A. E. \& Schrage, M., 1985. Size spectra of benthic biomass and metabolism. Mar. Ecol. Prog. Ser. 26, 161-173.

Glutz von Blotzheim, U. N., Bauer, K. M. \& Bezzel, E., 1975. Handbuch der Vögel Mitteleuropas. Akad. Verl.Ges., Wiesbaden, $840 \mathrm{pp}$.

Goethe, F., 1980. Shelduck Tadorna tadorna (L.). In: Birds of the Wadden Sea. Ed. by C. J. Smit \& W. J. Wolff. Balkema, Rotterdam, 37-48.

Griffiths, D., 1992. Size, abundance, and energy use in communities. - J. Anim. Ecol. 61, 307-315.

Hartmann-Schröder, G., 1981. The ragworm Nereis diversicolor. In: Invertebrates of the Wadden Sea. Ed. by N. Dankers, H. Kühl \& W. J. Wolff. Balkema, Rotterdam, 113-114.

Harvey, M. \& Vincent, B., 1990. Density, size distribution, energy allocation and seasonal variations in shell and soft tissue growth at two tidal levels of a Macoma balthica (L.) population. - J. exp. mar. Biol. Ecol. 142, 151-168.

Heip, C., Herman, R. \& Vincx, M., 1984. Variability and productivity of meiobenthos in the Southern Bight of the North Sea. - Rapp. P.-v. Réun. Cons. int. Explor. Mer. 183, 51-56.

Höfmann, H. \& Hoerschelmann, H., 1969. Nahrungsuntersuchungen bei Limikolen durch Mageninhaltsanalysen. - Corax 3, 7-22.

Jacobsen, V. H., 1967. The feeding of the lugworm Arenicola marina (L.). Quantitative studies. Ophelia 4, 91-109.

Jansson, B. O. \& Wulff, F., 1977. Ecosystem analysis of a shallow sound in the northern Baltic - a joint study by the Askö group. - Contr: Askö Lab. Univ. Stockh. 18, 1-160.

Jensen, K. T. \& Siegismund, H. R., 1980. The importance of diatoms and bacteria in the diet of Hydrobia-species. - Ophelia (Suppl.) 1, 193-199.

Jonge, V. de, 1992. Physical processes and dynamics of microphytobenthos in the Ems Estuary (The Netherlands). Thesis, Univ. Groningen, $176 \mathrm{pp}$.

Krüger, F., 1964. Messungen der Pumpaktivität von Arenicola marina (L.) im Watt. - Helgoländer wiss. Meeresunters. 11, 70-91.

Lauckner, G., 1986. Ecological effects of larval trematode infestation on littoral marine invertebrate populations. In: Parasitology-Quo vadit? Ed. by M. J. Howell. Australian Academy of Sciences, Canberra, 391-398. (Proc. 6th Int Congr. Parasitol.)

Morse, D. R., Stork, N. E. \& Lawton, J. H., 1988. Species number, species abundance and body length relationships of arboreal beetles in Bornean lowland rain forest trees. - Ecol. Ent. 13, 25-37.

Mouritsen, K. N. \& Jensen, K. T., 1992. Choice of microhabitat in tactile foraging dunlins Calidris alpina: the importance of sediment penetrability. - Mar. Ecol. Prog. Ser. 85, 1-8.

Piersma, T., Engelmoer, H., Altenburg, W. \& Mes, R., 1980. A wader expedition to Mauretania. Bull. Wader Stud. Group 29, 14.

Pihl, L., 1985. Food selection and consumption of mobile epibenthic fauna in shallow marine areas. Mar. Ecol. Prog. Ser. 22, 169-179.

Píl, L. \& Rosenberg, R., 1984. Food selection and consumption of the shrimp Crangon crangon in some shallow marine areas in western Sweden. - Mar. Ecol. Prog. Ser. 15, 159-168. 
Plagmann, J., 1939. Emährungsbiologie der Garnele Crangon vulgaris. - Helgoländer wiss. Meeresunters. 2, 113-162.

Raffaelli, D. \& Milne, H., 1987. An experimental investigation of the effects of shorebird and flatfish predation on estuarine invertebrates. - Estuar. coast. Shelf Sci. 24, 1-13.

Reise, K., 1978. Experiments on epibenthic predation in the Wadden Sea. - Helgoländer wiss. Meeresunters. 31, 55-101.

Reise, K., 1981. The role of predation on intertidal flats. In: Invertebrates of the Wadden Sea. Ed. by N. Dankers, H. Kühl \& W. J. Wolff. Balkema, Rotterdam, 105-107.

Reise, K., 1985. Tidal flat ecology. Springer, Berlin, $191 \mathrm{pp}$.

Reise, K., Herre, E. \& Sturm, M., 1994. Biomass and abundance of macrofauna in intertidal sediments of Königshafen in the northern Wadden Sea. - Helgoländer Meeresunters. 48, 201-215.

Remmert, H., 1980. Ökologie. Springer, Berlin, $304 \mathrm{pp}$.

Riisgard, H. U., Vedel, A., Boye, H. \& Larsen, P. S., 1992. Filter-net structure and pumping activity in the polychaete Nereis diversicolor: effects of temperature and pump-modelling.- Mar. Ecol. Prog. Ser. 83, 79-89.

Schwinghamer, P., Hargrave, B., Peer, D. \& Hawkins, C. M., 1986. Partitioning of production and respiration among size groups of organisms in an intertidal benthic community, - Mar. Ecol. Prog. Ser. 31, 131-142.

Smith, P. C. \& Evans, P. R., 1973. Studies of shorebirds at Lindisfarne, Northumberland. I. Feeding ecology and behaviour of the bar-tailed godwit. - Wildfowl 24, 135-139.

Vlas, J. de, 1979. Secondary production by tail regeneration in a tidal flat population of lugworms (Arenicola marina), cropped by flatfish. - Neth. J. Sea Res. 13, 362-393.

Wolff, W. J. \& Zijlstra, J. J., 1981. The common shrimp Crangon crangon. In: Invertebrates of the Wadden Sea. Ed. by N. Dankers, H. Kühl \& W. J. Wolff. Balkema, Rotterdam, 122-123.

Zwarts, L. \& Blomert, A.-M., 1992. Why knot Calidris canutus takes medium-sized Macoma balthica when six prey species are available. - Mar. Ecol. Prog. Ser. 83, 113-128. 